\title{
PENGEMBANGAN BUKU PANDUAN PELAKSANAAN BIMBINGAN KELOMPOK DENGAN METODE DISKUSI UNTUK MENINGKATKAN MOTIVASI BELAJAR SISWA
}

\author{
Eva Oktavia ${ }^{1}$, Sholih ${ }^{2}$, Arga Satrio Prabowo ${ }^{3}$ \\ ${ }^{123}$ Prodi Bimbingan dan Konseling \\ Fakultas Keguruan dan Ilmu Pendidikan \\ Universitas Sultan Ageng Tirtayasa \\ Email : 1evaoktavia998@gmail.com, \\ ${ }^{2}$ sholih@untirta.ac.id, ${ }^{3}$ argasatrio@gmail.com
}

\begin{abstract}
Abstrak
Salah satu upaya untuk meningkatkan motivasi belajar siswa adalah dengan bimbingan kelompok. Penelitian ini bertujuan untuk mengembangkan buku panduan pelaksanaan bimbingan kelompok dengan metode diskusi, tujuannya adalah untuk memudahkan guru Bimbingan dan Konseling dalam melakksanakan bimbingan kelompok dan memberikan gambaran serta inovasi dalam pelaksanaan bimbingan kelompok dengan metode diskusi dan diharapkan mampu meningkatkan motivasi belajar siswa melalui kegiatan bimbingan kelompok yang menarik. Metode yang digunakan adalah metode penelitian dan pengembangan (R\&D) dengan mengadaptasi model ADDIE yang di sederhanakan dalam tiga tahapan yaitu tahap analisis, perancangan dan pengembangan. Teknik pengumpulan data yang di gunakan yaitu melakukan uji kelayakan ahli terhadap produk yang dikembangkan. Adapun teknik analisis data untuk menguji kelayakan produk pengembangan adalah dengan menggunakan kriteria kelayakan dari Arikunto. Hasil uji ahli materi menyatakan kesesuain materi memperoleh persentase sebesar $71 \%$, mendorong keingintahuan memperoleh persentase sebesar $62,5 \%$, teknik penyajian, lugas, komunikatif, kesesuain dengan kaidah Bahasa memperoleh persentase sebesar 75\%. Sedangkan hasil uji ahli media menyatakan ukuran buku memperoleh persentase sebesar 75\%, desain cover buku memperoleh persentase sebesar 92\% dan desain isi buku memperoleh presentase sebesar 81\%. Hasil uji kelayakan produk pengembangan yang telah dilakukan oleh satu dosen ahli media dan satu dosen ahli materi dari keduanya diperoleh hasil penilaian rata-rata adalah $80 \%$, artinya buku panduan pelaksanaan bimbingan kelompok dengan metode diskusi yang dibuat peneliti termasuk dalam kriteria "layak".
\end{abstract}

Kata kunci: Motivasi Belajar, Pengembangan buku panduan pelaksanaan bimbingan kelompok dengan metode diskusi.

\begin{abstract}
One of the efforts to increase student motivation is group guidance. This study aims to develop a guidebook for the implementation of group guidance with the discussion method, the aim is to facilitate Guidance and Counseling teachers in carrying out group guidance and provide an overview and innovation in the implementation of group guidance with the discussion method and are expected to increase student learning motivation through group guidance activities interesting. The method
\end{abstract}


used is the research and development $(R \& D)$ method by adapting the ADDIE model which is simplified in three stages, namely the analysis, design and development stages. The data collection technique used is to conduct an expert due diligence on the product being developed. The data analysis technique to test the feasibility of product development is to use the eligibility criteria of Arikunto. The results of the material expert test stated that the suitability of the material obtained a percentage of $71 \%$, encouraging curiosity to obtain a percentage of $62.5 \%$, presentation techniques, straightforward, communicative, conformity with language rules obtained a percentage of $75 \%$. Meanwhile, the test results from media experts stated that book size obtained a percentage of 75\%, book cover design received a percentage of $92 \%$ and book content design obtained a percentage of $81 \%$. The results of the feasibility test for product development that have been carried out by one media expert lecturer and one material expert lecturer from both of them obtained an average rating of $80 \%$, meaning that the guidebook for the implementation of group guidance with the discussion method created by the researcher is included in the "proper" criteria.

\section{Keywords: Learning Motivation, Development of guide book for group guidance implementation with discussion method}

\section{PENDAHULUAN}

Menurut UU No. 20 Tahun 2003 tentang SISDIKNAS yang dimaksud dengan Pendidikan adalah sebuah usaha sadar dan terencana untuk mewujudkan suasana belajar dan proses pembelajaran agar peserta didik secara aktif mengembangkan potensi dirinya untuk memiliki kekuatan spiritual keagamaan, pengendalian diri, kepribadian, kecerdasan, akhlak mulia, serta keterampilan yang diperlukan dirinya, masyarakat, bangsa dan negara. Pendidikan diharapkan mampu membina manusia agar menjadi lebih baik lagi dan mengajarkan manusia pada kedewasaaan dan kemandirian, dengan pendidikan yang baik tentunya akan menghasilkan generasi yang kompeten dalam bidangnya. Pendidikan merupakan hak dan kewajiban bagi seluruh manusia karena dari pendidikan kita akan belajar menjadi seorang yang berkarakter dan memiliki daya saing yang tinggi untuk berprestasi. Pendidikan merupakan proses ketika budaya non fisik dipelihara atau dikembangkan dalam pengasuh anak-anak (Rifai, 2017).

Menurut Fatah (2004) diantara problematika yang perlu di antisipasi dalam lembaga pendidikan antara lain adalah kurangnya memadukan motif-motif kuat yang sudah ada, tidak adanya kejelasan tujuan yang hendak dicapai, tidak adanya rumusan tujuan sementara, kurangnya merangsang pencapaian kegiatan, tidak adanya situasi persaingan belajar, kurangnya menumbuhkan persaingan dengan diri sendiri, kurang maksimalnya laporan hasil yang dicapai, serta tidak adanya contoh yang positif dari 
pendidik. Menurut Uno (2001) tentang indikator motivasi belajar, antara lain dapat diklasifikasikan sebagai berikut yaitu adanya hasrat dan keinginan berhasil, adanya dorongan dan kebutuhan dalam belajar, adanya harapan dan cita-cita masa depan, adanya penghargaan dalam belajar, adanya kegiatan yang menarik dalam belajar, serta adanya lingkungan belajar yang kondusif, sehingga memungkinkan seorang siswa dapat belajar dengan baik.

Berdasarkan hasil studi pendahuluan yang peneliti lakukan di SMA Negeri 5 Kota Serang dengan menggunakan Angket Kebutuhan Peserta Didik (AKPD) diperoleh hasil bahwa bidang belajar merupakan bidang tertinggi yaitu sebesar 33,09\%, diikuti dengan bidang pribadi sebesar 31,90\% kemudian bidang sosial yaitu sebesar $21,18 \%$ dan terakhir bidang karir sebesar 13,83\%. Beberapa butir pernyataan yang menunjukkan bidang belajar merupakan butir tertinggi adalah siswa jarang sekali mengunjungi perpustakaan untuk membaca dengan persentase sebesar 89,07\%, siswa merasa masih kesulitan dalam memahami pelajaran tertentu dengan persentase sebesar 89,07\%, siswa masih suka menunda-nunda tugas sekolah atau pekerjaan rumah (PR) dengan persentase sebesar $79,03 \%$, siswa belum bisa belajar secara rutin dengan persentase sebesar $79,03 \%$, siswa belum menemukan cara belajar yang efektif dengan persentase sebesar $77,06 \%$ dan siswa belum tahu cara untuk membangkitkan semangat belajar dengan persentase sebesar $77,06 \%$. Berdasarkan hasil asesmen dan gejala yang Nampak maka masalah yang terjadi merujuk pada motivasi belajar yang rendah.

Berdasarakan latarbelakang yang telah diuraikan dan atas dasar pemikiran yang sudah diuraikan, maka peneliti akan melakukan penelitian pengembangan buku panduan pelaksanaan bimbingan kelompok dengan metode diskusi untuk meningkatkan motivasi belajar siswa.

\section{KAJIAN TEORITIK}

Motivasi menurut Donald (Hamalik, 2011) motivasi adalah perubahan energi dalam diri atau pribadi seseorang yang ditandai dengan timbulnya perasaan dan reaksi untuk mencapai tujuan. Sedangkan menurut Suryabrata (2006) motivasi diartikan sebagai keadaan yang terdapat dalam diri seseorang yang mendorongnya untuk melakukan aktifitas tertentu guna pencapaian suatu tujuan.

Belajar menurut Hamalik (2001) adalah bentuk pertumbuhan atau perubahan dalam diri seseorang yang dinyatakan dalam cara-cara berperilaku yang baru berkat pengalaman dan pelatihan. Menurut Sardiman (2005) belajar merupakan perubahan dalam penampilan sebagai hasil praktek.

Menurut Sardiman (2015) yang dimaksud dengan motivasi belajar adalah keseluruhan daya penggerak di dalam diri siswa yang menimbulkan kegiatan belajar 
yang menjamin kelangsungan dari kegiatan belajar dan memberi arah pada kegiatan belajar sehingga tujuan yang dikehendaki oleh subjek belajar tercapai. Berdasarkan pengertian yang telah dijelaskan sebelumnya dapat disimpulkan yang dimaksud dengan motivasi belajar adalah kondisi psikologis yang mendorong siswa untuk belajar secara sungguh-sungguh, yang pada akhirnya akan terbentuk cara belajar siswa yang sistematis, penuh konsentrasi dan dapat menyeleksi kegiatan-kegiatan yang mendukungnya dalam mengembangkan diri.

\section{Menurut Wibowo (2005) yang} dimaksud dengan bimbingan kelompok adalah suatu kegiatan kelompok dimana pemimpin kelompok menyediakan informasi- informasi dan mengarahkan diskusi agar anggota kelompok menjadi lebih sosial untuk membantu anggota kelompok mencapai tujuan Bersama. Gazda mengungkapkan yang dimaksud dengan bimbingan kelompok di sekolah adalah proses pemberian informasi kepada sekelompok siswa untuk menyusun rencana dan keputusan yang tepat (Prayitno \& Amti, 2012). Sedangkan menurut Tohirin (2015) yang dimaksud dengan layanan bimbingan kelompok adalah suatu cara memberikan bantuan (bimbingan) kepada individiu (siswa) melalui kegiatan kelompok. Menurut Prayitno (2012) tujuan bimbingan kelompok adalah berkembangnya sosialisasi siswa khususnya kemampuan komunikasi anggota kelompok dan meluruskan perasaan, persepsi, pikiran, wawasan dan sikap yang objektif, sempit dan tidak efektif.

Menurut Tohirin (2007) yang dimaksud dengan diskusi kelompok adalah suatu cara dimana siswa memperoleh kesempatan untuk memecahkan masalah secara bersama-sama. Sedangkan menurut Romlah (2001) diskusi kelompok merupakan percakapan yang sudah direncanakan antara tiga orang atau lebih untuk memecahkan masalah atau untuk menjelaskan suatu persoalan, dibawah pimpinan seseorang pemimpin.

Pengembangan dalam penelitian ini adalah proses, cara, perbuatan mengembangkan sebuah buku panduan pelaksanaan bimbingan kelompok dengan metode diskusi untuk meningkatkan motivasi belajar siswa. Pengembangan yang dilakukan pada pengembangan ini menggunakan buku panduan sebagai media layanan bimbingan dan konseling.

\section{METODE}

Prosedur penelitian dan pengembangan buku panduan menggunakan model yang disesuaikan dengan kebutuhan peneliti yaitu model desain sistem pembelajaran yang disebut ADDIE (Sugiyono, 2012).

Model pengembangan ADDIE terdiri dari lima tahapan yang meliputi analisis (Analysis), desain (Design), pengembangan 
(Development), selanjutnya implementasi (Implementation) serta evaluasi (Evaluation) (Sugiyono, 2015). Peneliti memiliki keterbatasan dalam melakukan penelitian R\&D aecara utuh sehingga peneliti hanya menggunakan beberapa tahapan saja, hanya sampai tahap ketiga yaitu pengembangan (Development).

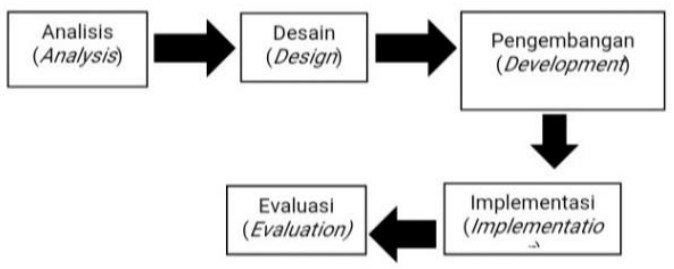

Gambar 1. Langkah Penelitian pengembangan ADDIE (Sugiyono, 2015)

Menurut Sugiyono (2015s) yang dimaksud dengan populasi adalah wilayah generalisasi yang terdiri atas obyek/subyek yang mempunyai kualitas dan karakteristik tertentu yang ditetapkan oleh peneliti untuk dipelajari dan kemudian ditarik kesimpulannya. Populasi yang akan digunakan oleh peneliti adalah peserta didik kelas XI di SMA Negeri 5 kota Serang. Peneliti hanya mengambil 2 kelas dari keseluruhan kelas XI yang ada di SMA Negeri 5 Kota Serang yang berjumlah kurang lebih 50 siswa dengan mempertimbangkan karakteristik yang dibutuhkan oleh peneliti serta berdasarkan rekomendasi dari guru BK di SMA Negeri 5 Kota Serang.

Menurut Sugiyono (2015) yang dimaksud dengan sampel adalah bagian dari jumlah dan karakteristik yang dimiliki oleh populasi. Sampel adalah sebagian dari jumlah dan karakteristik yang dimiliki oleh populasi tersebut atau merupakan bagian kecil dari anggota populasi yang diambil menurut prosedur tertentu sehingga dapat mewakili populasinya. Penelitian ini menggunakan teknik purposive sampling. Peneliti hanya mengambil 2 kelas dari keseluruhan kelas XI yang ada di SMA Negeri 5 Kota Serang, dengan mempertimbangkan karakteristik yang dibutuhkan oleh peneliti serta berdasarkan rekomendasi dari guru BK di SMA Negeri 5 Kota Serang.

Instrumen yang digunakan dalam penelitian dan pengembangan ini digunakan untuk validasi kelayakan media layanan bimbingan kelompok untuk ahli materi dan ahli media. Sebelum angket digunakan, maka angket harus memenuhi syarat valid dan reliabel. Selain valid, angket yang akan digunakan juga harus memenuhi syarat reliabel.

Reliabilitas angket dapat diuji menggunakan koefisien Cronbachalpha yang disajikan pada Persamaan 3.1 dibawah. Angket dinyatakan reliabel jika nilai koefisien Cronbach-alpha memiliki nilai minimal 0,7 (Arikunto, 2010). Jika nilai alpha $>0.7$ artinya reliabilitas mencukupi (sufficient reliability) sementara jika alpha $>0.80$ ini mensugestikan seluruh item reliabel dan 
seluruh tes secara konsisten memiliki reliabilitas yang kuat.

$$
r_{11}=\frac{k}{k-1} \times\left\{1-\frac{\sum S_{i}}{S_{t}}\right\}
$$

$$
\begin{array}{ll}
r_{11} & =\text { Koefisien Realibilitas } \\
k & =\text { Jumlah item } \\
\Sigma S_{i} & =\text { Jumlah Varians skor tiap-tiap item } \\
S_{t} & =\text { Varians total }
\end{array}
$$

Instrumen yang di gunakan mengacu pada aspek-aspek instrumen penilaian BSNP (Badan Standar Nasional Pendidikan) sehingga pada penelitian ini peneliti tidak menguji validitas dan realibitas intrumen.

Lembar validasi untuk ahli media digunakan untuk menguji kelayakan dari buku panduan bimbingan kelompok dengan metode diskusi untuk meningkatkan motivasi belajar siswa dari aspek kelayakan kegrafikan. Kisikisi intrumen yang akan dimuat angket validasi terdapat dalam Tabel 1 berikut:

Tabel 1 Kisi-kisi Intrumen Validasi Ahli Media

\begin{tabular}{|c|c|c|c|}
\hline $\begin{array}{c}\text { Variabel } \\
\text { Penelitian }\end{array}$ & Aspek & Indikator & No item \\
\hline & & $\begin{array}{c}\text { Ukuran Buku } \\
\text { Panduan }\end{array}$ & 1 \\
\cline { 3 - 4 } $\begin{array}{c}\text { Buku } \\
\text { Panduan } \\
\text { Bimbingan } \\
\text { Kelompok }\end{array}$ & Kelayakan & $\begin{array}{c}\text { Desain Cover } \\
\text { Buku } \\
\text { Kanduan }\end{array}$ & $2,3,4,5,6,7$ \\
\cline { 3 - 4 } & & $\begin{array}{c}\text { Desain Isi } \\
\text { Buku }\end{array}$ & $8,9,10,11,12,13,14,15$ \\
Panduan & \\
\hline
\end{tabular}

Lembar validasi untuk ahli media digunakan untuk menguji kelayakan dari buku panduan bimbingan kelompok dengan metode diskusi untuk meningkatkan motivasi belajar siswa dari aspek kelayakan isi, penyajian, dan bahasa. Kisi kisi intrumen yang akan

\begin{tabular}{|c|c|c|c|}
\hline $\begin{array}{l}\text { Variabel } \\
\text { Penelitian }\end{array}$ & Aspek & Indikator & No Item \\
\hline \multirow{6}{*}{$\begin{array}{c}\text { Buku } \\
\text { Panduan } \\
\text { Bimbingan } \\
\text { Kelompok }\end{array}$} & \multirow[t]{2}{*}{$\begin{array}{l}\text { Kelayakan } \\
\text { Isi }\end{array}$} & $\begin{array}{l}\text { Kesesuaian } \\
\text { Materi }\end{array}$ & $\begin{array}{c}1,2,3,11,12 \\
13,14\end{array}$ \\
\hline & & $\begin{array}{l}\text { Mendorong } \\
\text { Keingintahuan }\end{array}$ & 4,5 \\
\hline & $\begin{array}{l}\text { Kelayakan } \\
\text { Penyajian }\end{array}$ & $\begin{array}{c}\text { Teknik } \\
\text { Penyajian }\end{array}$ & 6 \\
\hline & \multirow[t]{3}{*}{$\begin{array}{c}\text { Kelayakan } \\
\text { Bahasa }\end{array}$} & Lugas & 7,8 \\
\hline & & Komunkatif & 9 \\
\hline & & $\begin{array}{c}\text { Kesesuaian } \\
\text { Dengan Kaidah } \\
\text { Bahasa }\end{array}$ & 10 \\
\hline
\end{tabular}
dimuat angket validasi terdapat dalam Tabel 2 berikut :

Tabel 2 Kisi-kisi Intrumen Validasi Ahli

Materi

Data hasil penilaian terhadap kelayakan produk pengembangan buku panduan pelaksanaan bimbingan kelompok dengan metode diskusi dianalisis secara deskriptif. Penentuan tingkat kelayakan produk dari Arikunto (2009) seperti pada tabel 3 berikut:

Tabel 3 Kriteria Kelayakan Produk (Arikunto, 2009) 


\begin{tabular}{|l|l|}
\hline \multicolumn{1}{|c|}{ Skor Nilai (\%) } & \multicolumn{1}{|c|}{ Kelayakan } \\
\hline$<21 \%$ & Sangat tidak layak \\
\hline $21-40 \%$ & Tidak layak \\
\hline $40-60 \%$ & Cukup layak \\
\hline $60-80 \%$ & Layak \\
\hline $80-100 \%$ & Sangat layak \\
\hline
\end{tabular}

Rumus yang digunakan adalah sebagai berikut:

$P=\frac{\sum X}{\sum X i}(100 \%)$

Keterangan:

$P \quad=$ Persentase yang dicari

$\Sigma \mathrm{X}=$ = Jumlah Jawaban Responden

$\Sigma \mathrm{X} i=$ Jumlah Nilai Ideal

\section{HASIL DAN PEMBAHASAN}

\section{a. Penilaian Ahli Materi}

Penilaian yang di lakukan ahli materi meliputi Kelayakan isi, kelayakan penyajian dan kelayakan bahasa dengan indikator adalah kesesuaian materi, mendorong keingintahuan, teknik penyajian, lugas, komunikatif, dan kesesuaian dengan bahasa. Deskripsi hasil penilain akan peneliti jelaskan menjadi dua bagian, bagian pertama adalah hasil uji coba perhitungan kuantitatif dan pada bagian kedua adalah deskripsi hasil uji coba secara kualitatif. Berikut adalah hasil uji coba yang di dapatkan peneliti:

1. Deskripsi Kuantitatif Penilaian Ahli Materi

Tabel 4 Penilaian Ahli Materi

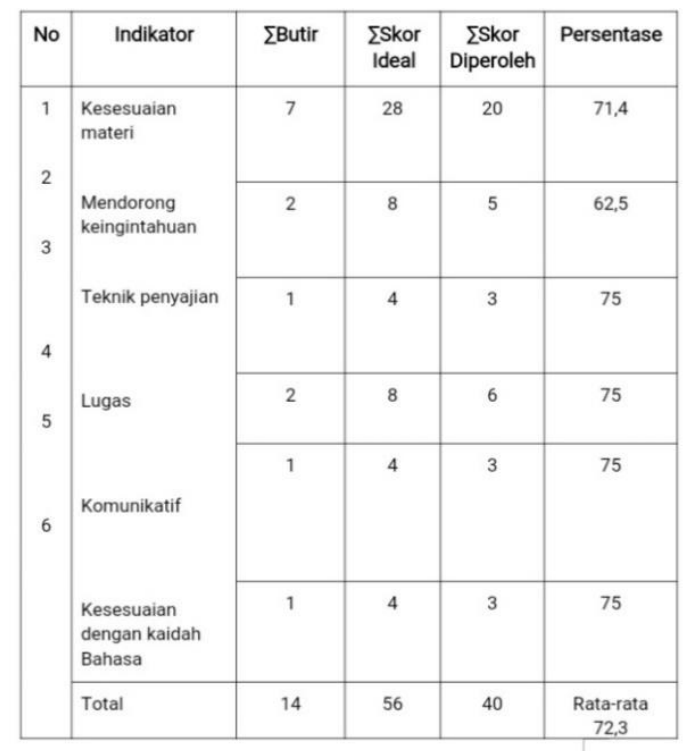

Penilaian ahli materi jika di gambarkan dengan diagram, adalah sebagai berikut:

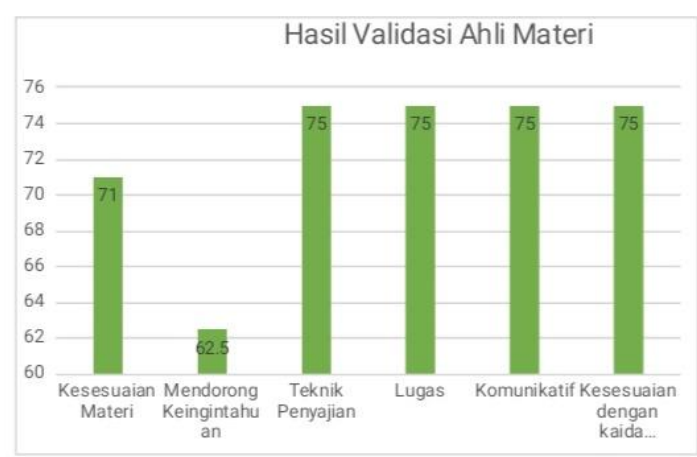

Gambar 2 Penilaian Ahli Materi

Berdasarkan tabel dan diagram di atas, dapat dijelaskan bahwa kesesuain materi memperoleh persentase sebesar $71 \%$, mendorong keingintahuan memperoleh persentase sebesar $62,5 \%$, teknik penyajian, lugas, komunikatif, kesesuain dengan kaidah Bahasa memperoleh persentase sebesar $75 \%$. Persentase terendah adalah sebesar $62,5 \%$ termasuk dalam kategori layak, 
dengan indikator mendorong keinigintahuan dan itemnya adalah mendorong rasa ingin tahu dan menciptakan kemampuan bertanya. Materi yang baik harus dapat menumbuhkan keingintahuan serta kreatifiitas siswa sehingga merangasang, memantapkan, menantang dan menggiatkan aktivitas pembaca (Susanti, 2012). Menurut ahli buku ini belum menggambarkan hal tersebut sehingga penilaiannya paling rendah diantara indikator yang lain. Persentase terakhir uji kelayakan buku panduan pelaksanaan bimbingan kelompok dengan metode diskusi memperoleh rata-rata hasil sebesar 72,3 \%. Berdasarkan kriteria penilaian oleh Arikunto (2009), perolehan hasil uji kelayakan ahli materi terhadap media yang dikembangkan dapat di katakan layak untuk di ujicobakan kepada calon pengguna.

2. Deskripsi Kualititatif Penilaian Ahli Materi

Media buku panduan pelaksanaan bimbingan kelompok dengan metode diskusi yang telah dikembangkan dianggap layak dan dapat di ujicobakan kepada calon pengguna untuk melihat respon pengguna terhadap media yang dikembangkan, dengan catatan untuk memperbaiki kekurangan dari segi konten dan materi berdasarkan masukan yang telah diberikan. Adapun masukan serta saran yang diberikan oleh ahli materi saat pelaksanaan uji kelayakan buku panduan pelaksanaan bimbingan kelompok dengan metode diskusi adalah kurangnya materi terkait evaluasi kegiatan bimbingan kelompok yang di gunakan terlalu umum.

\section{b. Penilaian Ahli Materi}

Penilaian yang di lakukan ahli materi meliputi aspek kegrafikan dengan indikatornya adalah ukuran buku panduan, desain cover dan isi buku panduan. Deskripsi hasil penilain akan peneliti jelaskan menjadi dua bagian, bagian pertama adalah hasil uji coba perhitungan kuantitatif dan pada bagian kedua adalah deskripsi hasil uji coba secara kualitatif. Berikut adalah hasil uji coba yang di dapatkan peneliti:

1. Deskripsi Kuantitaif Penilaian Ahli Media

Tabel 5 Penilaian Ahli Media

\begin{tabular}{|c|c|c|c|c|c|}
\hline No & Indikator & ¿Butir & $\begin{array}{l}\text { ¿Skor } \\
\text { Ideal }\end{array}$ & $\begin{array}{c}\sum \text { Skor } \\
\text { Diperoleh }\end{array}$ & Persentase \\
\hline \multirow[t]{2}{*}{1} & \multirow[t]{2}{*}{$\begin{array}{l}\text { Ukuran buku } \\
\text { panduan }\end{array}$} & 1 & 4 & 3 & 75 \\
\hline & & 6 & 24 & 21 & 92 \\
\hline 2 & $\begin{array}{l}\text { Desain cover } \\
\text { buku panduan }\end{array}$ & 8 & 32 & 26 & 81 \\
\hline \multirow[t]{2}{*}{3} & $\begin{array}{l}\text { Desain isi buku } \\
\text { panduan }\end{array}$ & & & & \\
\hline & Total & 15 & 60 & 50 & $\begin{array}{c}\text { Rata-rata } \\
82,6\end{array}$ \\
\hline
\end{tabular}


Penilaian ahli media jika di gambarkan dengan diagram, adalah sebagai berikut:

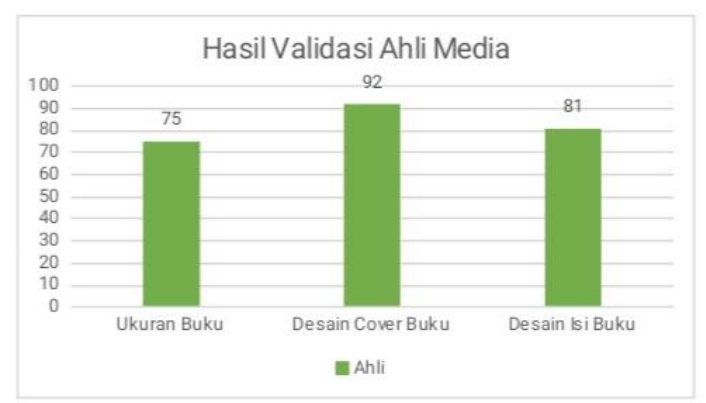

Gambar 3 Penilaian Ahli Media

Berdasarkan tabel dan diagram di atas, dapat dijelaskan bahwa ukuran buku memperoleh persentase sebesar $75 \%$, desain cover buku memperoleh persentase sebesar $92 \%$ dan desain isi buku memperoleh presentase sebesar $81 \%$. Persentase terendah adalah $75 \%$ dengan keterangan ukuran buku, penggunaan format berstandar biasanya menggunakan ukuran format buku dengan font antara 12-14 pts untuk times new roman, atau sebanding dengannya ukuran yang lain kecuali judul maka di sesuaikan dengan kebutuhan (Susanti, 2012). Menurut ahli media indikator ukuran buku belum sesuai dengan apa yang dijelaskan sebelumnya, buku yang dikembangkan masih dapat diperbaiki lagi ukurannya sehingga mendapatkan ukuran buku yang pas.

Secara keseluruhan, perolehan hasil uji kelayakan ahli media terhadap media yang dikembangkan dapat di katakan sangat layak berdasarkan kriteria penilaian oleh Arikunto (2009). Persentase terakhir uji kelayakan buku panduan pelaksanaan bimbingan kelompok dengan metode diskusi memperoleh rata-rata hasil sebesar $82,6 \%$ dan dapat di ujicobakan kepada calon pengguna.

2. Deskripsi Kualitatif Penilaian Ahli Media

Hasil uji kelayakan media buku panduan pelaksanaan bimbingan kelompok dengan metode diskusi yang telah dikembangkan dianggap sangat layak dan dapat di ujicobakan kepada calon pengguna untuk melihat respon pengguna terhadap media yang dikembangkan, dengan catatan untuk memperbaiki kekurangan dari segi konten dan materi berdasarkan masukan yang telah diberikan. Adapun masukan serta saran yang diberikan oleh ahli media saat pelaksanaan uji kelayakan buku panduan pelaksanaan bimbingan kelompok dengan metode diskusi adalah konten media pembelajaran sesuai dengan need assessment yang di lakukan sebelum merancang konsep media, penyajian media pembelajaran BK cukup menarik dan mudah dipahami, sajikan ruang dalam bentuk penugasan yang 
menghubungkan komunikasi antar guru dan siswa.

Produk pengembangan yang berupa buku panduan pelaksanaan bimbingan kelompok ini menghasilkan beberapa fitur yaitu cover, materi, kutipan, gambar ilustrasi dan lampiran yang mendukung keidealan sebuah buku panduan. Produk pengembangan telah dilakukan uji kelayakan oleh ahli, dengan hasil uji kelayakan seperti yang telah di jelaskan sebelumnya. Hasil uji kelayakan yang telah di lakukan terhadap buku panduan pelaksanaan bimbingan kelompok untuk meningkatkan motivsi belajar siswa menjadi tolak ukur kelayakan pengembangan buku panduan. Hasil penilaian ahli menunjukkan bahwa produk tersebut layak untuk diimplementasikan, ditunjukkan dengan skor penilaian yang diperoleh peneliti dari kedua ahli yaitu sebesar $80 \%$.

Menurut Greene dan Petty (Tarigan, 2009) mengemukakan bahwa buku panduan harus memiliki kualitas yang baik yaitu buku haruslah menarik minat pembaca yang menggunakannya, mampu memberi motivasi kepada pemakainya, dapat menstimulasi aktivitas siswa, membuat ilustrasi yang menarik penggunanya dan mempunyai landasan, prinsip dan sudut pandang tertentu yang melandasi konsep-konsep yang digunakan harus jelas. Pendapat Greene dan Petty (Tarigan, 2009) juga menjadi dasar peneliti dalam menyusun buku panduan. Buku panduan yang dikembangkan oleh peneliti memiliki desain tampilan yang menarik, terdapat kutipan dari tokoh terkenal yang menambah kesan menarik dan motivasi untuk membaca, konten yang terdapat dalam buku panduan sesuai dengan kebutuhan guru dan siswa, materi yang di muat dalam buku panduan di buat untuk mempermudah guru dalam mengaplikasikan kepada siswa dan menambah wawasan guru tentang bimbingan kelompok. Berdasarkan pendapat Greene dan Petty (Tarigan, 2009) dengan buku panduan yang dikembangkan peneliti, maka buku yang di hasilkan peneliti dapat dikatakan layak dan berkualitas baik. Sehingga dengan adanya produk pengembangan buku panduan merupakan suatu solusi yang tepat dan buku panduan ini layak untuk diimplementasikan.

\section{PENUTUP}

\section{Simpulan}

Berdasarkan hasil penelitian dan pengembangan buku panduan pelaksanaan bimbingan dan kelompok 
dengan metode diskusi untuk meningkatkan motivasi belajar siswa dapat di simpulksn bahwa:

1. Penelitian dan pengembangan yang telah di lakukan oleh peneliti menghasilkan produk pelaksanaan bimbingan kelompok dengan metode diskusi untuk meningkatkan motivasi belajar siswa berupa buku panduan pelaksanaan bimbingan kelompok untuk guru BK.

2. Produk hasil pengembangan secara keseluruhan di katakan layak, artinya memenuhi kriteria penilaian uji ahli. Baik dari segi kelayakan isi yaitu kesesuaian materi dan mendorong keingintahuan, baik dari segi kelayakan penyajian yaitu teknik penyajian, baik dari segi kelayakan bahasa yaitu lugas, komunikatif dan kesesuaian dengan kaidah bahasa. Serta dari segi kegrafikan yaitu ukuran cover, desain cover dan desain isi buku.

3. Sementara berdasarkan hasil validasi pada produk pengembangan yang di lakukan dua ahli, diperoleh hasil rata-rata uji ahli materi sebesar $72,3 \%$ pada tabel 4.1 dan hasil uji media sebesar $82,6 \%$ pada tabel 4.2 . skor rata-rata hasil uji ahli adalah sebesar $80 \%$. Berdasarkan kriteria kelayakan produk pada tabel 3.4 maka buku panduan pengembangan yang di susun peneliti berada dalam kriteria "Layak".

\section{Saran}

Berdasarkan hasil penelitian dan pengembangan yang di lakukan, maka peneliti meberikan saran-saran sebagai berikut:

1. Bagi guru BK, hasil penelitian dan pengembangan prooduk dapat di gunakan sebagai referensi buku pelaksanaan bimbingan kelompok dengan metode diskusi untuk meningkatkan motivasi belajar siswa.

2. Bagi pengguna, sebaiknya membaca dan menyimak terlebih dahulu rangkaian kegiatan bimbingan kelompok beserta tugas dan langkahlangkah pelaksanaan sebelum mengimplementasi kegiatan.

3. Bagi peneliti selanjutnya, perlu di lakukannya pengembangan lebih lanjut dengan melakukan uji coba atau implementasi produk dengan memperhatikan dan menyusun rancangan waktu penelitian agar pengembangan produk terstruktur dan terencana dengan baik.

\section{DAFTAR PUSTAKA}

A.M. Sardiman. 2001. Interaksi Dan Motivasi Belajar Mengajar. Jakarta: Raja Grafindo Persada. 
Arikunto. 2008. Dasar-dasar Evaluasi Pendidikan. Jakarta: Bumi Aksara

Arikunto, S., et al. 2008. Penelitian Tindakan Kelas (Cetakan ke VII). Jakarta: Bumi Aksara

Arikunto, S. 1998. Prosedur Penelitian. Jakarta: Rieneka Cipta

Fattah, N. 2004. Konsep Manajemen Berbasis Sekolah (MBS) dan Dewan Sekolah. Bandung: Bani Quraisy

Gulo, W. 2002. Strategi Belajar Mengajar. Jakarta: PT. Grasindo.

Hamalik, O. 2001. Proses Belajar Mengajar. Jakarta: Bumi Aksara

Latief. 2014. Berita Buruk Pendidikan Indoensia. Diakses pada alamat web:

https://edukasi.kompas.com/read/ 2014/12/02/18365971/Berita.Buru k.Pendidikan.Indonesia. Di akses pada tanggal 14 Februari 2020

Maslow, A. 2010. Motivation And Personality. Jakarta: Rajawali

Nashar, H. 2004. Peranan Motivasi dan Kemampuan Awal Dalam Kegiatan Pembelajaran. Jakarta: Delia Press

Prayitno \& Amti. 2008. Dasar-dasar Bimbingan dan Konseling. Jakarta: Rineka Cipta

Romlah, T. 2001. Teori dan Praktik Bimbingan dan Konseling Kelompok. Malang: Universitas Negeri Malang Press
Sardiman, A.M. 1986. Interaksi dan Motivasi Belajar Mengajar. Jakarta: Grafindo Persada

Suryabrata, S. 2006. Metodologi Penelitian. Jakarta: Pt. Raja Grafindo Persada

Sugiyono. 2015. Metode Penelitian Pendidikan. Bandung: Alfabeta

Uno, H.B. 2011. Teori Motivasi dan Pengukurannya: Analisis di Bidang Pendidikan. Jakarta: Bumi Aksara

UU. RI. NO. 20 tahun 2003. Tentang Sistem Pendidikan Nasional (SIKDIKNAS). Bandung: Citra Umbara

Yusuf, A.M. 2005. Metodologi Penelitian (Dasar-Dasar Pendidikan Ilmiah). Padang: UNP Press 